\title{
The Initial Attack Sites of a Streptomyces Alkalophilic Proteinase on Oxidized Insulin B-Chain
}

\author{
Toshihiro Nakanishi and Takehiko Yamamoto \\ Faculty of Science, Osaka City University, Sumiyoshi-ku, Osaka \\ Received April 7, 1975
}

\begin{abstract}
The sites on oxidized insulin B-chain substrate initially attacked by an alkalophilic proteinase from a Streptomyces sp., were investigated under incubation conditions employing one part enzyme to one thousand parts of substrate at $0^{\circ} \mathrm{C}$.

Analysis of the peptides produced after 10 to 40 seconds of incubation revealed that the enzyme, which has an optimum $\mathrm{pH}$ of around 13, first attacks two peptide linkages "-Leu (15)Tyr (16)-Leu (17)-" of the oxidized insulin B-chain with equal efficiency.
\end{abstract}

In our previous papers, ${ }^{1,2}$ a number of peptides and amino acids were shown to be produced by the alkalophilic proteinase when incubated with oxidized insulin B-chain. However, only two of some 30 synthetic peptides examined, namely Poly-Lys and Cbz-TyrGly $\cdot \mathrm{NH}_{2}$, were susceptible to this enzyme. Upon analyses of the peptides produced from the oxidized insulin B-chain, it was concluded that the peptide linkages of $-\operatorname{Ser}(9)$. His(10)-, - - Leu(11) - Val(12)-, -Phe(25) - Tyr(26)and -Lys(29)-Ala(30)- of the oxidized insulin B-chain were all susceptible to this enzyme. However, in that investigation, a ratio of one part enzyme to 100 parts substrate and relatively long incubation periods at $37^{\circ} \mathrm{C}$ were used. Hence, all of the peptide linkages of the substrate susceptible to the enzyme would have been attacked making it impossible to distinguish those peptide linkages which are most sensitive to the enzyme.

The purpose of the present report is to identify those peptide linkages of the oxidized insulin B-chain which are attacked first by the enzyme by employing a higher ratio of substrate to enzyme, shorter incubation times and a lower incubation temperature.

\section{MATERIALS AND METHODS}

1. Enzyme. The purified Streptomyces alkalophilic proteinase used in this study was obtained by repeated crystallization." The enzyme activity was the same as that described in our previous paper. ${ }^{21}$

2. Substrate. The oxidized insulin B-chain used as the substrate was prepared from crystalline bovine pancreatic insulin (Sigma Chemical Co.) according to the method of Griffin et al.,3) and purified by successive chromatography on columns of Dowex $50 \mathrm{~W}-$ $\mathrm{X} 2$ and Sephadex G-25. The homogeneity of the purified B-chain was confirmed by paper chromatography, N-terminal amino acid analysis using the DNP-method and amino acid composition.

3. Experimental procedure. The initial attack sites were determined by the following method. To three tubes containing $64 \mathrm{mg}$ (20.6 $\mu$ moles) of oxidized insulin B-chain substrate dissolved in $1.5 \mathrm{ml}$ of $1.0 \%$ trimethylamine, $\mathrm{pH} 11.6,64 \mu \mathrm{g}$ of the alkalophilic proteinase dissolved in $0.5 \mathrm{ml}$ of $1.0 \%$ trimethylamine at $0^{\circ} \mathrm{C}$ were added. After 10,20 , and 40 seconds of incubation at $0^{\circ} \mathrm{C}$, respectively, the enzyme reactions were terminated by the addition of $1.0 \mathrm{ml}$ of acetic acid. For the control, the same amount of B-chain substrate $(64 \mathrm{mg})$ was dissolved directly in $3.0 \mathrm{ml}$ of $10 \%$ acetic acid containing $64 \mu \mathrm{g}$ of the enzyme. The reaction mixtures were then concentrated in vacuo to remove as much of the acetic acid as possible and then lyophilized after bringing their total volumes to about $50 \mathrm{ml}$ with water.

4. Purification of peptides. Each dried digest was subsequently dissolved in $2.0 \mathrm{ml}$ of $0.2 \mathrm{M}$ pyridineacetate, $\mathrm{pH} 3.0$, and applied to a Dowex $50 \mathrm{~W}-\mathrm{X} 2$ column previously equilibrated with the same buffer, and eluted by a linear gradient of pyridine-acetate buffer from $0.2 \mathrm{M}, \mathrm{pH} 3.0$ to $2.0 \mathrm{M}, \mathrm{pH} 5.0$. The final elution was carried out using $8.5 \mathrm{M}$ pyridine-acetate buffer, pH 5.5 . 
5. Detection of peptides in eluates. Peptides in the eluates were detected by the alkaline hydrolysis method. ${ }^{4}$ Three tenths $\mathrm{ml}$ of each eluate was transfered to a test tube to which $1.0 \mathrm{ml}$ of $2.5 \mathrm{~N} \mathrm{NaOH}$ was added and the tubes were immersed into a boiling water bath for $2.0 \mathrm{hr}$. After the resulting hydrolysates were cooled to $4^{\circ} \mathrm{C}, 1.0 \mathrm{ml}$ of $30 \%$ acetic acid and $2.0 \mathrm{ml}$ of ninhydrin solution $(20 \mathrm{~g}$ of ninhydrin dissolved in $750 \mathrm{ml}$ of methyl cellosolve and mixed with $250 \mathrm{ml}$ of $4.0 \mathrm{M}$ acetate buffer, $\mathrm{pH} 5.5$ containing $1 \mathrm{~g}$ of $\mathrm{SnCl}_{2}$ ) were added, The resulting color densities for the hydrolysates were then measured spectrophotometrically at $570 \mathrm{~nm}$.

6. Isolation of peptides. Each eluate containing ninhydrin positive material was subjected to paper chromatography to determine the homogeneity of its contents by the descending method using butanol: pyridine: $\mathrm{AcOH}: \mathrm{H}_{2} \mathrm{O}(15: 10: 3: 12)$ as the solvent. Preparative paper chromatography was applied to fractions shown to contain more than one peptide using filter paper previously washed with the solvent. The peptides thus isolated on paper were recovered by eluting them with $30 \%$ acetic acid.

7. Peptide and amino acid analysis. The isolated and purified peptides were then dinitrophenylated and their $\mathrm{N}$-terminal amino acids determined according to the method of Fraenkel-Contrat et al. ${ }^{5}$ Amino acid compositions of the peptides were analysed on an auto-amino acid analyzer (034 Hitachi Liquid Chromatograph) after hydrolysis with $6.0 \mathrm{~N} \mathrm{HCl}$ at $110^{\circ} \mathrm{C}$ for $24 \mathrm{hr}$ in sealed tubes.

\section{RESULTS}

\section{Separation of peptides and amino acids}

As shown in Fig. 1, the digest obtained by incubating oxidized insulin B-chain with alkalophilic proteinase as described in $\mathrm{MA}^{-}$ TERIALS AND METHODS was separated into seven fractions by chromatography on a column of Dowex 50W-X2. Fraction (F) 6 and $F 7$, the latter appearing as a shoulder of the former which was oxidized insulin Bchain itself, were further purified by chromatography on a column of Sephadex G-25. As shown in Fig. 2, they were separated clearly into two fractions.

Paper chromatographic analysis (Toyo Roshi No. 50) of each fraction revealed that F 4, F 5, F 6 and F 7 were homogeneous. However, F 1, F 2, and F 3 contained at least two ninhydrin ${ }^{6}$ and Rydon-Smith ${ }^{7}$

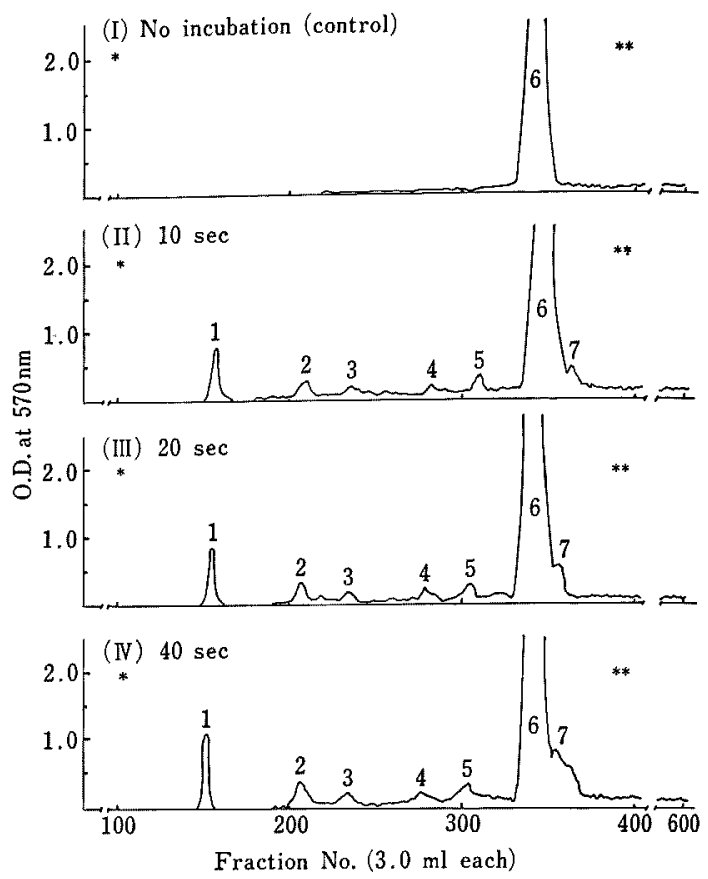

Frg. 1. Chromatography of the Proteinase Digest of Oxidized Insulin B-Chain on a Dowex $50 \mathrm{~W}-\mathrm{X} 2$ Column $\left(38^{\circ} \mathrm{C}\right)$.

Column, $0.9 \times 98 \mathrm{~cm}$; sample applied, $2.0 \mathrm{ml}$ which contained $21 \mu$ moles each on the basis of B-chain; incubation period: I, no incubation (control); II, $10 \mathrm{sec}$; III, $20 \mathrm{sec}$; IV, $40 \mathrm{sec}$; buffer used, $0.2 \mathrm{M}$ pyridine-acetate, pH 3.0; *linear gradient from $0.2 \mathrm{M}$, pH 3.0 to $2.0 \mathrm{M}$, pH $5.0 ; * * 8.5 \mathrm{M}, \mathrm{pH} 5.5$; flow rate, $18.0 \mathrm{ml} / \mathrm{hr}$.

positive spots (Fig. 3). These fractions were then subjected to preparative paper chromatography to isolate each component. F 1 subsequently yielded $F$ la and $F$ lb but the yields of peptides or amino acids contained in F 2 and in F 3 were too small and therefore not subjected to further study.

\section{Determination of $\mathrm{N}$-terminal amino acids and amino acid compositions of peptides isolated}

Each of the peptides isolated above was dinitrophenylated using one fourth to one half portions of the peptides except for $F$, in which case $0.1 \mu$ mole was employed (amount based on results of amino acid analysis). Phe was determined to be the N-terminus for each peptides in $\mathrm{F} 5$ and $F$ 7. The N- 


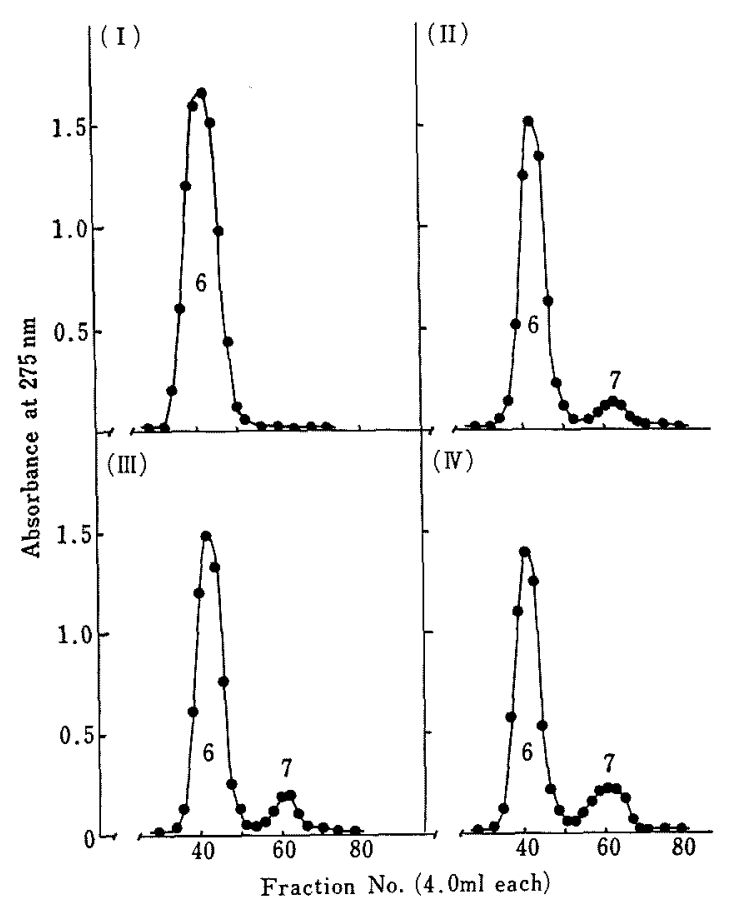

FIG. 2. Separation of F 6 and F 7 Obtained in Fig. 1 by Gel Filtration on a Column of Sephadex G-25.

Column, $1.6 \times 150 \mathrm{~cm} ; 1 / 10 \mathrm{M}$ acetic acid; sample applied, (I) $\sim$ (IV) $4 \mathrm{ml}$ with $10 \%$ acetic acid; flow rate, $30 \mathrm{ml} / \mathrm{hr}$.

terminus for peptides in other fractions were not investigated because of the small quanti- ties of the peptides available. Instead, those were used to obtain information concerning their amino acid compositions.

The amino acid composition of the peptides was determined on the portions remaining from the above experiment. The analytical data are presented in Table $I$ together with the $\mathrm{N}$-terminal amino acid for each peptide. $F 1$ and F 3 contained a mixture of two peptides as determined by the molar ratio of their amino acid compositions. F 2, F 4 and F 5 also contained contaminating peptides but their concentrations were too small ( $3 \sim$ $5 \%$ of the major peptide) to be analyzed.

The results presented in Table I show that F 2 and $F 7$ contained the main peptides produced by the action of Streptomyces alkalophilic proteinase on the oxidized insulin Bchain substrate. The peptide linkages therefore involved are "-Leu (15)-Tyr (16)-" and "-Tyr (16)-Leu (17)-" of B-chain, respectively. The implications of these results are discussed in the following section.

\section{DISCUSSION}

As shown in Table I, the recovery yield of oxidized insulin B-chain following chromatography on a column of Dowex 50W-X2 under

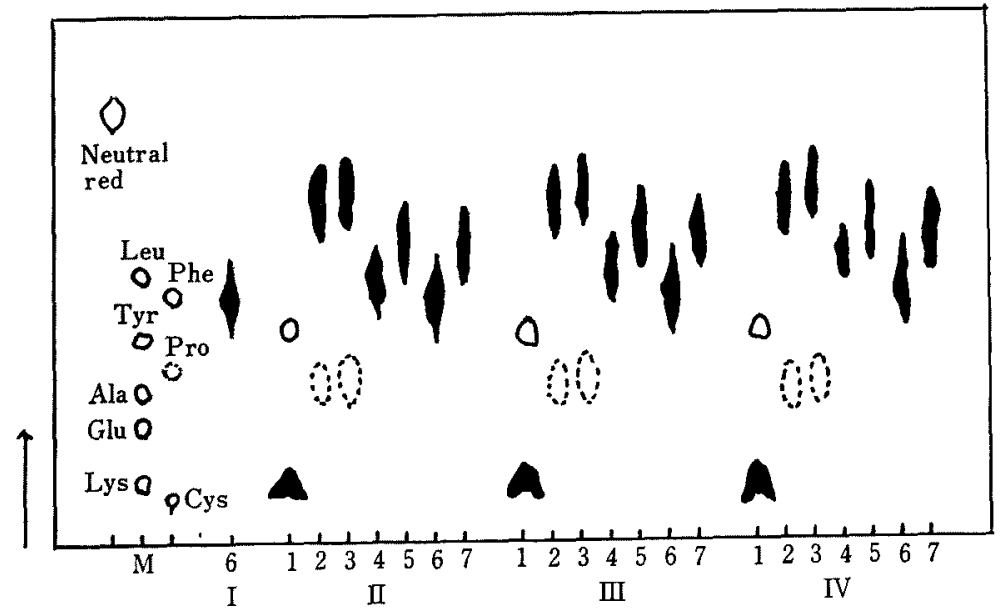

FIG. 3. Paper Chromatograms of Each Fraction Obtained in Figs. 1 and 2.

Carried out by the descending method using But: Pyr: AcOH: $\mathrm{H}_{2} \mathrm{O}(15: 10: 3: 12)$ as the solvent; location, initially sprayed ninhydrin in butanol saturated with $\mathrm{H}_{2} \mathrm{O}$, and then treated according ot the methed of Rydon and Smith.71 
Table I. Recovery Yields, N-Terminal Amino Acid and Probable Sequence of Peptides Produced from Oxidized Insulan B-Chain by the Enzyme

\begin{tabular}{|c|c|c|c|c|}
\hline Incubation, sec. & Fraction & $\begin{array}{c}\text { Recovery } \\
\text { yield, } \mu \text { moles }\end{array}$ & $\begin{array}{l}\text { N-terminal } \\
\text { amino acid }\end{array}$ & Site of B-chain \\
\hline $\begin{array}{l}\text { None } \\
\text { (I, control) }\end{array}$ & $\left\{\begin{array}{l}1 \mathrm{a} \\
1 \mathrm{a}^{\prime} \\
1 \mathrm{~b} \\
2 \\
3 \\
3 \mathrm{a}^{\prime} \\
4 \\
5 \\
6 \\
7\end{array}\right.$ & 15.26 & Phe & " $1-30 "$ \\
\hline \multirow{2}{*}{$\begin{array}{r}10 \\
\text { (II) }\end{array}$} & $\begin{array}{l}1 \mathrm{a} \\
1 \mathrm{a}^{\prime} \\
1 \mathrm{~b} \\
2 \\
3\end{array}$ & $\begin{array}{l}0.06 \\
0.03 \\
0.05 \\
0.62 \\
0.22\end{array}$ & $\begin{array}{l}\overline{-} \\
\text { Phe } \\
\text { Phe }\end{array}$ & $\begin{array}{l}" 19-21 " \\
" 7-9 " \\
" 16 ",(26) \\
" * 1-15 " \\
" 1-16 "\end{array}$ \\
\hline & $\begin{array}{l}3 a^{\prime} \\
4 \\
5 \\
6 \\
7\end{array}$ & $\begin{array}{r}0.04 \\
0.15 \\
11.29 \\
0.68\end{array}$ & $\begin{array}{l}\overline{-} \\
\text { Phe } \\
\text { Leu }\end{array}$ & $\begin{array}{l}“ 1-9 " \\
" 16-30 " \\
" 1-30 " \\
" 17-30 "\end{array}$ \\
\hline \multirow[t]{2}{*}{$\begin{array}{c}20 \\
\text { (III) }\end{array}$} & $\begin{array}{l}1 \mathrm{a} \\
1 \mathrm{a}^{\prime} \\
1 \mathrm{~b} \\
2 \\
3\end{array}$ & $\begin{array}{l}0.08 \\
0.04 \\
0.08 \\
0.64 \\
0.28\end{array}$ & $\begin{array}{l}\overline{-} \\
\text { E } \\
\text { Phe }\end{array}$ & $\begin{array}{l}\text { "19-21"” } \\
\text { "7-9" } \\
" 16 ",(26) \\
" 1-15 " \\
" 1-16 "\end{array}$ \\
\hline & $\begin{array}{l}3 \mathrm{da} \\
4 \\
5 \\
6 \\
7\end{array}$ & $\begin{array}{r}0.08 \\
0.16 \\
10.97 \\
0.77\end{array}$ & $\begin{array}{l}\text { Phe } \\
\text { Phe } \\
\text { Leu }\end{array}$ & $\begin{array}{l}\text { “ } 1-9 " \\
" 16-30 " \\
" 1-30 " \\
" 17-30 "\end{array}$ \\
\hline $\begin{array}{c}40 \\
\text { (IV) }\end{array}$ & $\begin{array}{l}1 \mathrm{a} \\
1 \mathrm{a}^{\prime} \\
1 \mathrm{~b} \\
2 \\
3 \\
3 \mathrm{a}^{\prime} \\
4 \\
5 \\
6 \\
7\end{array}$ & $\begin{array}{r}0.09 \\
0.04 \\
0.06 \\
0.82 \\
0.31 \\
0.02 \\
0.07 \\
0.26 \\
10.32 \\
1.19\end{array}$ & $\begin{array}{l}= \\
\overline{-} \\
\text { Phe } \\
\text { Phe } \\
= \\
\text { Tyr } \\
\text { Phe } \\
\text { Leu }\end{array}$ & 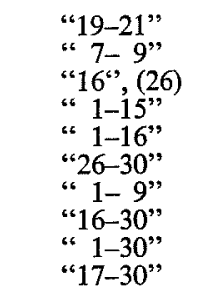 \\
\hline
\end{tabular}

The fractions symbolized with alphabets and primes were those separated by paper chromatography and those found in the amino acid analysis, respectively. Oxidized insulin B-chain, Phe Val Asn Gin His Leu $\mathrm{CySO}_{3} \mathrm{H}$ Gly Ser His Leu Val Glu Ala Leu Tyr Leu Val $\mathrm{CySO}_{3} \mathrm{H}$ Gly Glu Arg Gly Phe Phe Tyr Thr Pro Lys Ala.

the conditions described earlier was about $75 \%$. Considering this fact together with the recovery yields of $F 2$ and $F 7$, it appears that these peptides "Phe (1)-Leu (15)" and "Leu (17)-Ala (30)" of the substrate are the major ones among the peptides obtained.

From this result, it is concluded that the alkalophilic proteinase initially hydrolyzes the peptide linkages of "-Leu (15)-Tyr (16)-" and "-Tyr (16)-Leu (17)-" of the B-chain substrate with equal efficiency. This conclusion is supported by the fact that peptides in F 3 and F 5 are "Phe (1)-Tyr (16)" and "Tyr (16)Ala (30)" of the B-chain, respectively, though their yields were only about one third of F 2 and F 7 on a molar basis. Although the experiment was not specifically designed towards isolating free amino acids, tyrosine was detected and isolated in this investigation. Presumably, the free tyrosine was "Tyr (16)" of the B-chain released upon formation of the F 2 and F 7 peptides. Furthermore, it seems 


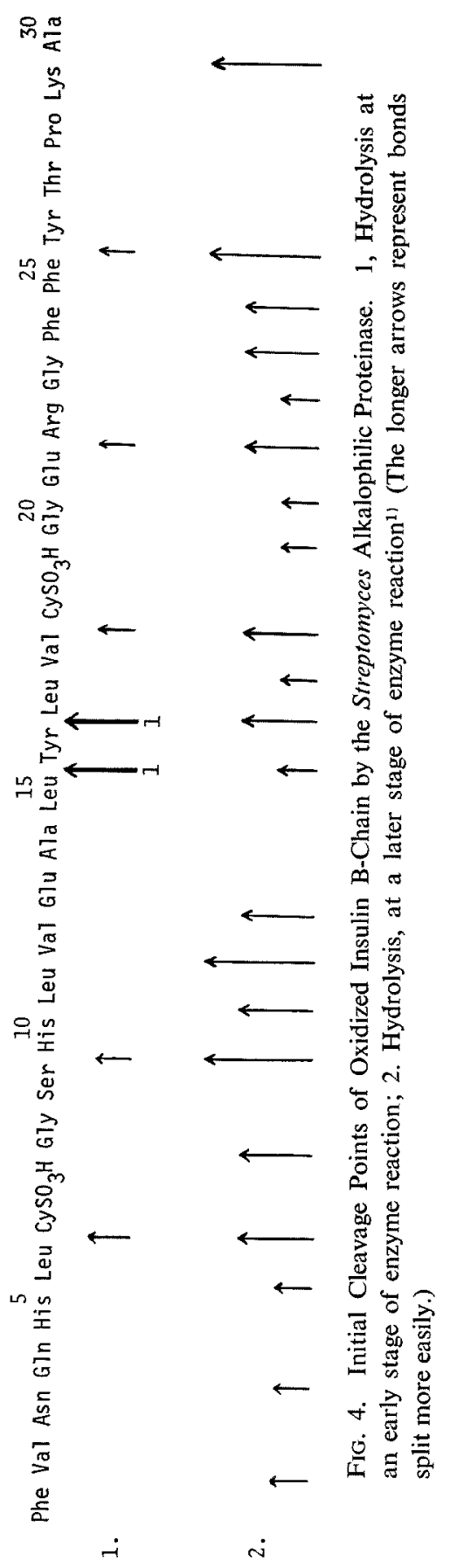

logical to consider that peptides in F 1a, F 1a', and $F \quad 4$ are those subsequently produced by the enzyme attacking the peptides resulting from the initial hydrolysis.

The conclusions reached in the present paper differs considerably from those in our previous report in which it was reported that the enzyme hydrolyzes most easily the peptide linkages of -Ser (9) · His (10)-, -Leu (11) - Val (12)-, -Phe (25) - Tyr (26)- and -Lys (29) - Ala (30)- of the B-chain. Furthermore, it was stated that the enzyme was capable of splitting additional peptide linkages of the substrate but at reduced rates. However, in those experiments, the ratio of $1 / 100$ of enzyme to substrate and incubation conditions of $37^{\circ} \mathrm{C}$ for $24 \mathrm{hr}$ were used. Under such conditions, it would be impossible to determine what the initial attack sites of the enzyme were on the B-chain substrate. Results from this and the previous paper do, however, strongly suggest that the peptides produced initially by the enzyme have less sensitive peptide linkages which are subsequently attacked by the enzyme to produce smaller peptides or free amino acids upon longer incubation. If transpeptidation occurred during the incubation periods employed, it is doubtful that the initial attack sites could have been determined by this method. Furthermore, although the purity of the enzyme used in this study has been determined by various standard methods, the possibility of it being contaminated with other proteinases can not be completely excluded.

In the present paper, the reaction products produced by the enzyme were analyzed at a time when major portion of the substrate still remained. Thus, the results obtained, enables us to conclude that the sites of oxidized insulin B-chain initially attacked by the enzyme are as shown in Fig. 4. Furthermore, since smaller peptides were detected under these conditions, it appears highly probable that the enzyme subsequently attacks the peptides initially produced rather than other sites on the original B-chain substrate.

Acknowledgement. The authors wish to express their sincere thanks to Dr. S. Oi of Osaka City University for his useful suggestions and kind discussions on this work. They are grateful to Dr. H. M. Nakata of Washington State University for his kind revision of the manuscript. 


\section{REFERENCES}

1) T. Nakanishi and T. Yamamoto, Agr. Biol. Chem., 38, 2391 (1974).

2) T. Nakanishi, Y. Matsumura, N. Minamiura and T. Yamamoto, ibid., 38, 37 (1974).

3) J. B. Griffin, F. W. Wagner and J. M. Prescott, J. Chromatography, 23, 280 (1966).

4) C. H. W. Hirs, S. Moore and W. H. Stein, J. Biol.
Chem., 219, 623 (1956).

5) H. Fraenkel-Conrat, J. I. Harris and A. L. Levy, "Methods of Biochemical Analysis," Vol. II, ed. by D. Glick, Academic Press Inc., N.Y., 1955, p. 359.

6) R. Consden, A. H. Gordon and A. J. P. Martin, Biochem. J., 38, 224 (1944),

7) H. N. Rydon and P. W. G. Smith, Nature, 169, 922 (1952). 